\title{
Bacterial Lawn Avoidance and Bacterial Two Choice Preference Assays in Caenorhabditis elegans \\ Jogender Singh ${ }^{1, \$, *}$ and Alejandro Aballay ${ }^{1}$
}

\author{
1Department of Molecular Microbiology \& Immunology, Oregon Health \& Science University, Portland, \\ Oregon, USA; ${ }^{\$}$ Current address: Department of Biological Sciences, Indian Institute of Science \\ Education and Research, Bhopal, Madhya Pradesh, India \\ *For correspondence: jogender@iiserb.ac.in
}

\begin{abstract}
[Abstract] Physical avoidance of pathogens is a crucial defense strategy used by the host to reduce pathogen infection. Hosts display the use of multiple strategies to sense and avoid pathogens, ranging from olfaction to sensing of damage caused by pathogen infection. Understanding various mechanisms of pathogen avoidance has the potential to uncover conserved host defense responses that are important against pathogen infections. Here, we describe protocols for studying pathogen lawn avoidance behavior as well as a change of bacterial preferences in the model nematode Caenorhabditis elegans. Besides, we describe the protocol for measuring preferences for pathogenic and nonpathogenic bacteria after training of the animals on pathogenic bacteria. These assays can be implemented in discovering various mechanisms of host learning that result in the avoidance of pathogens.
\end{abstract}

Keywords: Pathogen avoidance, Learning, Bacterial infection, Avoidance behavior, Defense response

[Background] A host uses multiple strategies to defend itself against pathogen infections (Medzhitov et al., 2012). Physical avoidance of pathogens is one of the various defense strategies used by the host (Medzhitov et al., 2012; Kavaliers et al., 2019; Singh and Aballay, 2020). Different sensory mechanisms, including chemosensation and elicitation of pain by nociceptor neurons upon detection of bacterial toxins, lead to avoidance behaviors. A deeper understanding of the mechanisms leading to pathogen avoidance holds the potential to uncover conserved host defense responses that are important against pathogen infections.

The nematode $C$. elegans has been widely used to understand pathogen avoidance behavior and associative learning. C. elegans appears to use multiple mechanisms to learn about pathogens resulting in elicitation of avoidance behaviors (Singh and Aballay, 2020). C. elegans can sense bacterial metabolites (Tran et al., 2017) as well as perturbations in core cellular activities (Melo and Ruvkun, 2012). Moreover, infection of the intestine can modulate neuroendocrine signaling to elicit avoidance behaviors (Singh and Aballay, 2019a and 2019b). Therefore, studying pathogen avoidance behavior and associative learning in $C$. elegans can help in deciphering various strategies used by a host in sensing pathogens. 


\section{Materials and Reagents}

1. $35 \mathrm{~mm}$ Petri dishes (Tritech Research, catalog number: T3500)

2. $60 \mathrm{~mm}$ Petri dishes (Tritech Research, catalog number: T3315)

3. $100 \mathrm{~mm}$ Petri dishes (Tritech Research, catalog number: T3361)

4. $14 \mathrm{ml}$ polypropylene round-bottom tube (VWR, catalog number: 60819-761)

5. $15 \mathrm{ml}$ centrifuge tube (VWR, catalog number: 21008-216)

6. $10 \mathrm{ml}$ syringe (BD, Bacto ${ }^{\mathrm{TM}}$, catalog number: 309604$)$

7. $0.2 \mu \mathrm{m}$ sterile syringe filter (VWR, catalog number: $28145-501)$

8. Escherichia coli strain OP50 (Caenorhabditis Genetics Center (CGC))

9. E. coli strain HT115 containing control RNAi plasmid (L4440) (Source BioScience, Ahringer C. elegans RNAi Collection)

10. E. coli strain HT115 expressing dsRNA for any gene of interest (Source BioScience, Ahringer $C$. elegans RNAi Collection)

11. Pseudomonas aeruginosa strain PA14 (Liberati et al., 2006)

12. C. elegans wild type Bristol N2 strain and/or any mutants of interest (CGC)

13. Isopropyl $\beta$-D-1-thiogalactopyranoside (IPTG) (Anatrace Product, catalog number: I1003 100 GM)

14. Sodium chloride $(\mathrm{NaCl})$ (Fisher Bioreagents, catalog number: BP358-1)

15. Calcium chloride $\left(\mathrm{CaCl}_{2}\right)$ (Sigma-Aldrich, catalog number: $\left.746495-500 \mathrm{G}\right)$

16. Magnesium sulfate anhydrous $\left(\mathrm{MgSO}_{4}\right)$ (Mallinckrodt, catalog number: $\left.\mathrm{A} 31 \mathrm{H} 10\right)$

17. Potassium phosphate monobasic $\left(\mathrm{KH}_{2} \mathrm{PO}_{4}\right)$ (Sigma-Aldrich, catalog number: P0662-2.5KG)

18. Potassium phosphate dibasic $\left(\mathrm{K}_{2} \mathrm{HPO}_{4}\right)$ (Sigma-Aldrich, catalog number: P3786-2.5KG)

19. Cholesterol (Sigma-Aldrich, catalog number: C8667-25G)

20. Ampicillin sodium salt (EMD Millipore, catalog number: 171254-25GM)

21. Bacto agar (BD, Bacto ${ }^{T M}$, catalog number: 214030 )

22. Bacto peptone (BD, Bacto ${ }^{\mathrm{TM}}$, catalog number: 211677$)$

23. Luria-Bertani (LB) broth (Sigma, catalog number: L3022-1KG)

24. 95\% ethanol (EMD Millipore, catalog number: EX0280-3)

25. $5 \mathrm{mg} / \mathrm{ml}$ cholesterol (see Recipes)

26. $100 \mathrm{mg} / \mathrm{ml}$ ampicillin stock (see Recipes)

27. $1 \mathrm{M}$ potassium phosphate buffer $(\mathrm{pH} 6)$ (see Recipes)

28. $1 \mathrm{M} \mathrm{CaCl}_{2}$ (see Recipes)

29. $1 \mathrm{M} \mathrm{MgSO}_{4}$ (see Recipes)

30. LB (see Recipes)

31. LB agar plates with and without ampicillin (see Recipes)

32. Nematode growth medium (NGM) agar plates (see Recipes)

33. RNAi plates (see Recipes)

34. Slow killing (SK) assay plates (see Recipes) 


\section{Equipment}

1. $500 \mathrm{ml}$ conical flask (VWR, catalog number: 89091-420)

2. $1,000 \mathrm{ml}$ conical flask (VWR, catalog number: 29136-106)

3. $2,000 \mathrm{ml}$ conical flask (VWR, catalog number: 89090-858)

4. Pipetman (Eppendorf, models: P20, P1000)

5. $20^{\circ} \mathrm{C}$ and $25^{\circ} \mathrm{C} \mathrm{C}$. elegans incubators (ThermoForma, model: 3920 )

6. Centrifuge (VWR, model: Clinical 50)

7. Platinum wire worm pick (made in the laboratory as described in Wollenberg et al., 2013) and alcohol burner (VWR, catalog number: 470199-936)

8. Orbital Shaker (Thermo Fisher Scientific, catalog number: SK4000)

9. Autoclave (Consolidated Sterilizer Systems, model: SR-24D)

10. Stereomicroscope (Leica, model: MZ7.5)

\section{Software}

1. Microsoft Excel

2. GraphPad Prism

\section{Procedure}

A. P. aeruginosa Lawn Avoidance Assay

\section{Day 1}

1. Synchronization of $C$. elegans

a. The assays are described for conditions where a gene is knocked down by RNAi (see Notes for details and assays with mutants). Transfer gravid adult N2 animals from E. coli OP50 plates to control RNAi plates (15-20 animals per RNAi plate), as well as RNAi plates for any gene of interest. Use one RNAi plate for each gene knockdown.

b. Incubate the plates at room temperature $\left(22^{\circ} \mathrm{C}\right)$ for $2 \mathrm{~h}$.

c. Remove the gravid adults from the RNAi plates and incubate the plates at $20^{\circ} \mathrm{C}$ for $72 \mathrm{~h}$ to obtain synchronized adult animals.

\section{Day 2}

2. Take out a vial of frozen $P$. aeruginosa PA 14 from $-80^{\circ} \mathrm{C}$ and immediately streak on an LB agar plate. Incubate the plate at $37^{\circ} \mathrm{C}$ for $12-14 \mathrm{~h}$.

\section{Day 3}

3. Pick a single colony of $P$. aeruginosa PA14, inoculate in $2 \mathrm{ml}$ of LB in a $14 \mathrm{ml}$ polypropylene 
round-bottom tube, place vertically on a shaker, and grow it for $10-12 \mathrm{~h}$ at $250 \mathrm{rpm}$ and $37^{\circ} \mathrm{C}$.

4. Place $20 \mu \mathrm{l}$ of inoculum on the center of $35 \mathrm{~mm}$ SK plates (Figure $1 \mathrm{~A}$ ) that are modified NGM (3.5\% instead of $2.5 \%$ peptone) plates. Let the inoculum dry at room temperature (20-30 $\mathrm{min}$ ). Invert the plates upside down (to prevent cracks in agar from drying out) and incubate at $37^{\circ} \mathrm{C}$ for $12 \mathrm{~h}$.

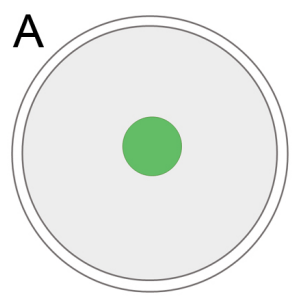

Avoidance plate

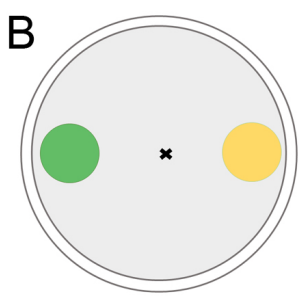

Two choice preference plate

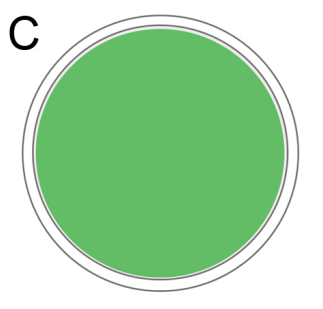

Training plate
P. aeruginosa

E. coli

Figure 1. Schematic representation of plates. A. Avoidance assay plates contain a spot of pathogenic bacteria in the center. B. The two-choice preference assay plates contain spots of the two types of bacteria placed diagonally opposite. The cross $(\mathbf{x})$ in the center of the twochoice preference assay plate indicates the site of the transfer of $C$. elegans. $C$. The surface of a training plate is fully covered with the pathogenic bacteria.

\section{Day 4}

5. Cool the $P$. aeruginosa plates from $37^{\circ} \mathrm{C}$ to room temperature for $30 \mathrm{~min}$.

6. Transfer 30 synchronized adult animals just outside $P$. aeruginosa lawn on SK plates. Use three $P$. aeruginosa plates per $C$. elegans strain/condition. Scrape off the residual $E$. coli from outside $P$. aeruginosa lawns on SK plates using platinum wire worm pick.

7. Incubate the plates with animals at $25^{\circ} \mathrm{C}$.

8. At various times of incubation $(2,4,8,12$, and $24 \mathrm{~h}$ or as required), count the number of animals that are inside the lawn, outside the lawn, and have crawled on the sidewalls of plates.

B. Naïve Two Choice Preference Assay

Day 1

1. Synchronize C. elegans as described for lawn avoidance assay (Procedure A, Day 1) and incubate at $20^{\circ} \mathrm{C}$ for $72 \mathrm{~h}$.

\section{Day 2}

2. Take out a vial of frozen $P$. aeruginosa PA14 from $-80^{\circ} \mathrm{C}$ and immediately streak on an LB agar plate. Incubate the plate at $37^{\circ} \mathrm{C}$ for $12-14 \mathrm{~h}$.

3. Streak RNAi bacteria (E. coli HT115) from $-80{ }^{\circ} \mathrm{C}$ on LB agar plates containing $100 \mu \mathrm{g} / \mathrm{ml}$ ampicillin. Incubate the plate at $37^{\circ} \mathrm{C}$ for $12-14 \mathrm{~h}$. 


\section{Day 3}

4. Pick a single colony of $P$. aeruginosa PA14, inoculate in $2 \mathrm{ml}$ of LB in a $14 \mathrm{ml}$ polypropylene round-bottom tube, place vertically on a shaker, and grow it for $10-12 \mathrm{~h}$ at $250 \mathrm{rpm}$ and $37^{\circ} \mathrm{C}$.

5. Pick a single colony of RNAi bacteria (E. coli HT115), inoculate in $10 \mathrm{ml}$ of LB with $100 \mu \mathrm{g} / \mathrm{ml}$ ampicillin in a $15 \mathrm{ml}$ tube, place horizontally on a shaker, and grow it for 10-12 h on at $250 \mathrm{rpm}$ and $37^{\circ} \mathrm{C}$.

6. After growth, concentrate RNAi bacteria $10-20$ fold by centrifuging at $5,000 \mathrm{rpm}$ for $5 \mathrm{~min}$ at room temperature.

7. Place $20 \mu \mathrm{l}$ of each inoculum diagonally opposite onto $35 \mathrm{~mm} \mathrm{SK}$ plates (Figure 1B). Let the inoculum dry at room temperature (20-30 min). Invert the plates upside down and incubate at $37^{\circ} \mathrm{C}$ for $12 \mathrm{~h}$.

\section{Day 4}

8. Cool the two-choice preference assay plates from $37^{\circ} \mathrm{C}$ to room temperature for $30 \mathrm{~min}$.

9. Transfer 30 synchronized adult animals to the centers of two-choice preference plates equidistant from both the lawns (Figure 1B). Use 3 two-choice preference assay plates per $C$. elegans strain/condition.

10. Scrape off residual E. coli from the center of the two-choice preference assay plates using a worm pick (as described in Procedure A, Day 4).

11. Incubate the plates with animals at $25^{\circ} \mathrm{C}$.

12. At various times of incubation $(2,4,8,12$, and $24 \mathrm{~h}$ or as required), count the number of animals that are on the E. coli lawn, P. aeruginosa lawn, outside the lawns, and have crawled on the sidewalls of plates.

\section{Trained Two Choice Preference Assay}

\section{Day 1}

1. Synchronize C. elegans as described for lawn avoidance assay (Procedure A, Day 1) and incubate at $20^{\circ} \mathrm{C}$ for $54 \mathrm{~h}$.

2. Take out a vial of frozen $P$. aeruginosa PA 14 from $-80^{\circ} \mathrm{C}$ and immediately streak on an LB agar plate. Incubate the plate at $37^{\circ} \mathrm{C}$ for $12-14 \mathrm{~h}$.

\section{Day 2}

3. Pick a single colony of $P$. aeruginosa PA14, inoculate in $2 \mathrm{ml}$ of LB in a $14 \mathrm{ml}$ polypropylene round-bottom tube, place vertically on a shaker, and grow it for $10-12 \mathrm{~h}$ at $250 \mathrm{rpm}$ and $37^{\circ} \mathrm{C}$. Store the $P$. aeruginosa plate at $4{ }^{\circ} \mathrm{C}$.

4. Place $20 \mu \mathrm{l}$ of inoculum on $35 \mathrm{~mm} \mathrm{SK}$ plates and spread it on the entire surface of the plates to obtain full lawns of $P$. aeruginosa (Figure $1 \mathrm{C}$ ). Invert the plates upside down and incubate at $37^{\circ} \mathrm{C}$ for $12 \mathrm{~h}$. 
5. Streak RNAi bacteria (E. coli HT115) from $-80{ }^{\circ} \mathrm{C}$ on LB agar plates containing $100 \mu \mathrm{g} / \mathrm{ml}$ ampicillin. Incubate the plate at $37^{\circ} \mathrm{C}$ for $12-14 \mathrm{~h}$.

\section{Day 3}

6. Pick a single colony of $P$. aeruginosa from the plate stored at $4{ }^{\circ} \mathrm{C}$ on Day 2 , inoculate in $2 \mathrm{ml}$ of LB in a $14 \mathrm{ml}$ polypropylene round-bottom tube, place vertically on a shaker, and grow it for 10-12 $\mathrm{h}$ at $250 \mathrm{rpm}$ and $37^{\circ} \mathrm{C}$.

7. Pick a single colony of RNAi bacteria (E. coli HT115), inoculate in $10 \mathrm{ml}$ of LB with $100 \mu \mathrm{g} / \mathrm{ml}$ ampicillin in a $15 \mathrm{ml}$ tube, place horizontally on a shaker, and grow it for 10-12 h on at $250 \mathrm{rpm}$ and $37^{\circ} \mathrm{C}$.

8. Cool the full lawn $P$. aeruginosa plates from $37^{\circ} \mathrm{C}$ to room temperature for at least $30 \mathrm{~min}$.

9. Transfer $54 \mathrm{~h}$ old synchronized $C$. elegans grown at $20{ }^{\circ} \mathrm{C}$ (from Day 1 ) to full lawns of $P$. aeruginosa, and incubate at $25^{\circ} \mathrm{C}$ for $18 \mathrm{~h}$. This will constitute the trained group of animals.

10. For control naïve animals, maintain the animals on their corresponding RNAi plates and incubate at $25^{\circ} \mathrm{C}$ for $18 \mathrm{~h}$ along with the training groups.

11. Prepare two-choice preference plates (Figure 1B) as described above in naïve two-choice preference assay (Procedure B, Day 3). Invert the plates upside down and incubate at $37^{\circ} \mathrm{C}$ for $12 \mathrm{~h}$.

\section{Day 4}

12. Cool the two-choice preference assay plates from $37^{\circ} \mathrm{C}$ to room temperature for $30 \mathrm{~min}$.

13. Transfer 30 synchronized adult animals from the full lawn $P$. aeruginosa plates to the center of a two-choice preference assay plate equidistant from both the lawns. Use 3 two-choice preference assay plates per $C$. elegans strain/condition. This will be the trained group of animals.

14. Likewise, transfer 30 synchronized adult animals from RNAi plates to the center of a two-choice preference assay plate equidistant from both the lawns. Use 3 two-choice preference assay plates per $C$. elegans strain/condition. This will be the control group of naïve animals.

15. Scrape off the residual bacteria from the centers of two-choice preference assay plates using a worm pick (as described in Procedure A, Day 4).

16. Incubate the plates with animals at $25^{\circ} \mathrm{C}$.

17. After $1 \mathrm{~h}$ of incubation, count the number of animals that are on the $E$. coli lawn, $P$. aeruginosa lawn, outside the lawns, and have crawled on the sidewalls of plates.

\section{Data analysis}

Percent lawn occupancy calculation: Count the number of animals inside and outside the bacterial lawns. Calculate percent lawn occupancy in Microsoft Excel as: 
Percent lawn occupancy $=\left(\frac{\mathrm{N}_{\text {on }}}{\left(\mathrm{N}_{\text {on }}+\mathrm{N}_{\text {off }}\right)}\right) \times 100$

Where, Non is the number of animals on the lawn, Noff is the number of animals outside the lawn. The animals that have crawled on the sidewalls of plates are excluded from calculations. Plot the time course of percent lawn occupancy using GraphPad Prism. The representative data in Figure $2 A$ show that animals that have knockdown of the genes aex -5 and nol- 6 have enhanced and slowed rates of avoidance of $P$. aeruginosa lawns, respectively.

Choice index calculation: Count the number of animals on the two types of bacterial lawns. Calculate $P$. aeruginosa choice index $(P$. aeruginosa $\mathrm{Cl})$ in Microsoft Excel as:

$$
\text { P.aeruginosa } \mathrm{CI}=\frac{[(\text { No. of worms on } P . \text { aeruginosa })-(\text { No. of worms on } E . \text { coli })]}{[(\text { No. of worms on P.aeruginosa })+(\text { No. of worms on } E . \text { coli })]}
$$

The $P$. aeruginosa $\mathrm{Cl}$ measures the preference of animals for $P$. aeruginosa with values ranging from -1 to 1 . The values $1,-1$, and 0 indicate that all animals are on $P$. aeruginosa, all animals are away from $P$. aeruginosa, and the same number of animals are on $P$. aeruginosa and $E$. coli, respectively. The $P$. aeruginosa $\mathrm{Cl}$ can be plotted for single time points (trained two-choice preference assay) or for a time course (naïve two-choice preference assay) using GraphPad Prism. The representative data in Figure $2 \mathrm{~B}$ show that naïve animals that have knockdown of the genes aex-5 and nol-6 have faster and slower switch in preference from $P$. aeruginosa to $E$. coli, respectively.

Use GraphPad Prism 8 for statistical analysis of data. Combine data from three independent experiments and calculate the mean and standard deviation (SD). Use multiple $t$-tests-one per time point and calculate $p$ value for a gene knockdown with respect to the control sample. Judge the data to be statistically significant when $P<0.05$.
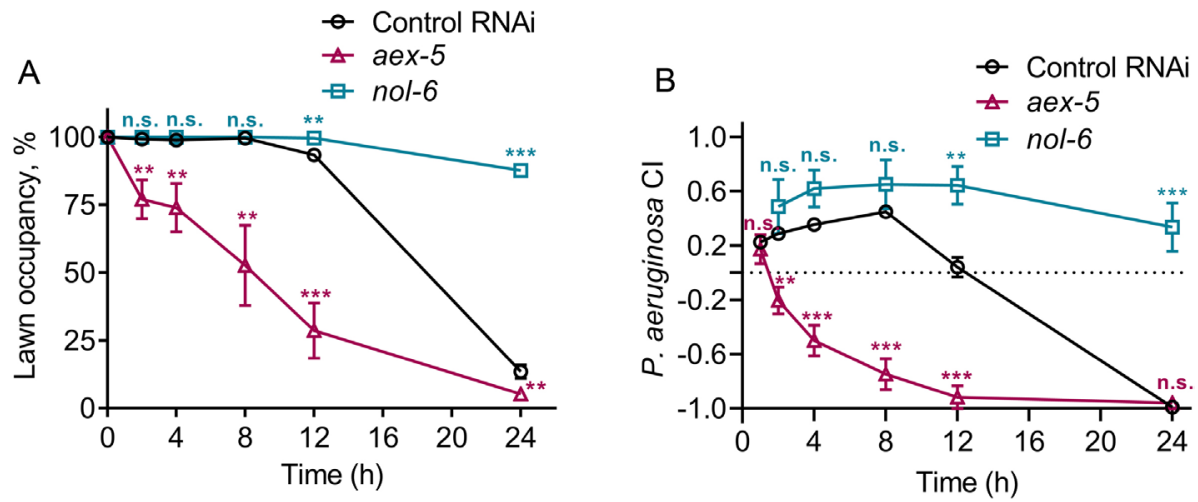

Figure 2. The time course of pathogen avoidance and change in bacterial preference. A. Time course of the percent occupancy of animals on $P$. aeruginosa lawns. B. Time course of the $P$. aeruginosa $\mathrm{Cl}$ of naïve animals in a two-choice preference assay containing one lawn of each 
P. aeruginosa and E. coli. See Singh and Aballay (2019b), for details on aex -5 and nol-6. Error bars denote SD from three independent experiments. $t$-test was used for each time point, and $P$ values for a gene knockdown (aex -5 or nol-6) were calculated with respect to the control RNAi. ${ }^{* * *} P<0.001,{ }^{* *} P<0.01$, and ${ }^{*} P<0.05$. n.s., non-significant.

\section{$\underline{\text { Notes }}$}

1. The assays are described for $P$. aeruginosa. However, these protocols can be used for other pathogens such as Serratia marcescens Db11.

2. The assays are described for conditions where a gene is knocked down by RNAi. The assays can be modulated for mutant animals where RNAi is not used. For such assays, carry out the synchronization of animals on E. coli OP50 plates and prepare lawns of E. coli OP50 and P. aeruginosa PA14 for two-choice preference assays.

3. The assays can be carried out at different levels of oxygen in a hypoxia chamber.

4. The incubation time of plates seeded with $P$. aeruginosa before animal exposure is critical for the kinetics of lawn avoidance. Differences in incubation time lead to different kinetics of avoidance (Singh and Aballay, 2019b).

5. There are several modifications of training protocol for two-choice preference assays. In some cases, training is carried out from L1 larval stage on plates that contain both $E$. coli and $P$. aeruginosa (Zhang et al., 2005).

6. P. aeruginosa is an opportunistic pathogen, and the PA14 strain is a highly virulent clinical isolate from a human patient. Handling of $P$. aeruginosa PA14 should be carried out under biosafety level 2 (BSL-2) laboratory practices.

\section{$\underline{\text { Recipes }}$}

1. $100 \mathrm{mg} / \mathrm{ml}$ ampicillin stock
a. Add $1 \mathrm{~g}$ ampicillin sodium salt into a $15 \mathrm{ml}$ tube and fill $\mathrm{dH}_{2} \mathrm{O}$ up to $10 \mathrm{ml}$
b. Stir until dissolved and filter-sterilize $(0.22 \mu \mathrm{m})$
c. Store in $1 \mathrm{ml}$ aliquots at $-20^{\circ} \mathrm{C}$ for up to 1 year

2. $5 \mathrm{mg} / \mathrm{ml}$ cholesterol
a. Add $500 \mathrm{mg}$ cholesterol to $100 \mathrm{ml} 95 \%$ ethanol
b. Stir until fully dissolved and filter-sterilize $(0.22 \mu \mathrm{m})$
c. Store the cholesterol solution at room temperature

3. $1 \mathrm{M}$ potassium phosphate buffer $(\mathrm{pH} 6)$
a. Add $23 \mathrm{~g} \mathrm{~K}_{2} \mathrm{HPO}_{4}, 118 \mathrm{~g} \mathrm{KH}_{2} \mathrm{PO}_{4}$ into a $1,000 \mathrm{ml}$ graduated bottle and fill $\mathrm{dH}_{2} \mathrm{O}$ up to 1,000 $\mathrm{ml}$
b. Stir until fully dissolved
c. Keep bottle lid loose and autoclave for $30 \mathrm{~min}$ at $121^{\circ} \mathrm{C}$ 
d. Store at room temperature

4. $1 \mathrm{M} \mathrm{CaCl}_{2}$

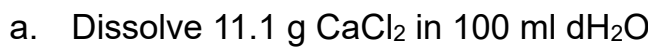
b. Autoclave for $30 \mathrm{~min}$ at $121^{\circ} \mathrm{C}$
c. Store at room temperature

5. $1 \mathrm{M} \mathrm{MgSO}_{4}$
a. Dissolve $12.0 \mathrm{~g} \mathrm{MgSO}_{4}$ in $100 \mathrm{ml} \mathrm{dH}_{2} \mathrm{O}$
b. Autoclave for $30 \mathrm{~min}$ at $121^{\circ} \mathrm{C}$
C. Store at room temperature

6. LB $(100 \mathrm{ml})$

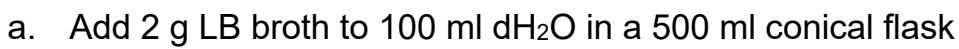
b. Autoclave for $30 \mathrm{~min}$ at $121^{\circ} \mathrm{C}$ and store at room temperature

7. LB agar plates without ampicillin
a. Add $10 \mathrm{~g} \mathrm{LB}$ broth, $7.5 \mathrm{~g}$ agar to $500 \mathrm{ml} \mathrm{dH}_{2} \mathrm{O}$ in a $1,000 \mathrm{ml}$ conical flask
b. Autoclave for $30 \mathrm{~min}$ at $121^{\circ} \mathrm{C}$ and cool to $55^{\circ} \mathrm{C}$
c. Pour $25 \mathrm{ml}$ each into $100 \mathrm{~mm}$ Petri dishes and incubate at room temperature for 2 days
d. Store at $4{ }^{\circ} \mathrm{C}$ in a box and use for 3 months

8. LB agar plates with ampicillin
a. Add $10 \mathrm{~g} \mathrm{LB}$ broth, $7.5 \mathrm{~g}$ agar to $500 \mathrm{ml} \mathrm{dH}_{2} \mathrm{O}$ in a $1,000 \mathrm{ml}$ conical flask
b. Autoclave for $30 \mathrm{~min}$ at $121^{\circ} \mathrm{C}$ and cool to $55^{\circ} \mathrm{C}$
c. Add $500 \mu \mathrm{l}$ of $100 \mathrm{mg} / \mathrm{ml}$ ampicillin while stirring
d. Pour $25 \mathrm{ml}$ each into $100 \mathrm{~mm}$ Petri dishes and incubate at room temperature for 2 days
e. Store at $4{ }^{\circ} \mathrm{C}$ in a box and use for 3 months

9. Nematode growth medium (NGM) agar plates seeded with E. coli OP50

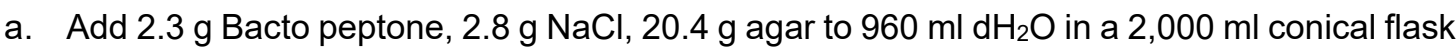
b. Autoclave for $30 \mathrm{~min}$ at $121^{\circ} \mathrm{C}$ and cool to $55^{\circ} \mathrm{C}$
c. Add $25 \mathrm{ml}$ of $1 \mathrm{M}$ potassium phosphate buffer, $1 \mathrm{ml}$ of $1 \mathrm{M} \mathrm{CaCl}_{2}, 1 \mathrm{ml}$ of $1 \mathrm{M} \mathrm{MgSO}_{4}$, and $1 \mathrm{ml}$ of $5 \mathrm{mg} / \mathrm{ml}$ cholesterol while stirring
d. Pour $8 \mathrm{ml}$ each into $60 \mathrm{~mm}$ Petri dishes and incubate at room temperature for 3 days
e. Inoculate a single colony of $E$. coli OP50 in $100 \mathrm{ml}$ of LB broth in a $500 \mathrm{ml}$ conical flask and incubate at $37^{\circ} \mathrm{C}$ at $225 \mathrm{rpm}$ shaking for $18-20 \mathrm{~h}$
f. Spot $400 \mu \mathrm{l}$ of E. coli OP50 culture on the center of plates that were incubated at room temperature for 3 days (from step 9d)
g. Grow E. coli OP50 on the plates for 3 days at room temperature
h. Store the plates at $4{ }^{\circ} \mathrm{C}$ in a box and use for 3 months

10. RNAi plates (NGM plates with $3 \mathrm{mM} \mathrm{IPTG}$ and $100 \mu \mathrm{g} / \mathrm{ml}$ ampicillin)
a. Add $2.3 \mathrm{~g}$ Bacto peptone, $2.8 \mathrm{~g} \mathrm{NaCl}, 20.4 \mathrm{~g}$ agar to $960 \mathrm{ml} \mathrm{dH} \mathrm{H}_{2} \mathrm{O}$ in a 2,000 ml conical flask
b. Autoclave for $30 \mathrm{~min}$ at $121^{\circ} \mathrm{C}$

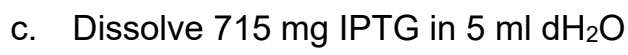


d. Cool media to $55^{\circ} \mathrm{C}$ while stirring

e. Add $25 \mathrm{ml}$ of $1 \mathrm{M}$ potassium phosphate buffer, $1 \mathrm{ml}$ of $1 \mathrm{M} \mathrm{CaCl}_{2}, 1 \mathrm{ml}$ of $1 \mathrm{M} \mathrm{MgSO}_{4}, 1 \mathrm{ml}$ of $5 \mathrm{mg} / \mathrm{ml}$ cholesterol, $5 \mathrm{ml}$ of IPTG solution prepared above (from step 10c), and $1 \mathrm{ml}$ of $100 \mathrm{mg} / \mathrm{ml}$ ampicillin while stirring

f. Pour $8 \mathrm{ml}$ each into $60 \mathrm{~mm}$ Petri dishes and incubate at room temperature for 3 days

g. Store the plates at $4{ }^{\circ} \mathrm{C}$ in a box and use for 3 months

11. Slow killing (SK) assay plates

a. Add $3.2 \mathrm{~g}$ Bacto peptone, $3.0 \mathrm{~g} \mathrm{NaCl}, 20 \mathrm{~g}$ agar to $960 \mathrm{ml} \mathrm{dH}_{2} \mathrm{O}$ in a 2,000 ml conical flask

b. Autoclave for $30 \mathrm{~min}$ at $121^{\circ} \mathrm{C}$ and cool to $55^{\circ} \mathrm{C}$

c. Add $25 \mathrm{ml}$ of $1 \mathrm{M}$ potassium phosphate buffer, $1 \mathrm{ml}$ of $1 \mathrm{M} \mathrm{CaCl}_{2}, 1 \mathrm{ml}$ of $1 \mathrm{M} \mathrm{MgSO}_{4}$, and $1 \mathrm{ml}$ of $5 \mathrm{mg} / \mathrm{ml}$ cholesterol while stirring

d. Pour $3.5 \mathrm{ml}$ each into $35 \mathrm{~mm}$ Petri dishes and incubate at room temperature for 3 days

e. Pack stacks of the plates in plastic bags, store at $4{ }^{\circ} \mathrm{C}$ in a box and use for 3 months

\section{Acknowledgments}

This work was supported by NIH grants GM0709077 and Al117911 (to A.A.). The wild type Bristol N2 strain used in this study was provided by the Caenorhabditis Genetics Center (CGC), which is funded by the NIH Office of Research Infrastructure Programs (P40 OD010440). The protocols have been adapted from previous work (Singh and Aballay, 2019b).

\section{Competing interests}

The authors declare that they have no conflicts of interest or competing interests.

\section{References}

1. Kavaliers, M., Ossenkopp, K. P. and Choleris, E. (2019). Social neuroscience of disgust. Genes Brain Behav 18(1): e12508.

2. Liberati, N. T., Urbach, J. M., Miyata, S., Lee, D. G., Drenkard, E., Wu, G., Villanueva, J., Wei, T. and Ausubel, F. M. (2006). An ordered, nonredundant library of Pseudomonas aeruginosa strain PA14 transposon insertion mutants. Proc Natl Acad Sci U S A 103(8): 2833-2838.

3. Medzhitov, R., Schneider, D. S. and Soares, M. P. (2012). Disease tolerance as a defense strategy. Science 335(6071): 936-941.

4. Melo, J. A. and Ruvkun, G. (2012). Inactivation of conserved C. elegans genes engages pathogen- and xenobiotic-associated defenses. Cell 149(2): 452-466.

5. Singh, J. and Aballay, A. (2019a). Microbial Colonization Activates an Immune Fight-and-Flight Response via Neuroendocrine Signaling. Dev Cell 49(1): 89-99 e84. 
6. Singh, J. and Aballay, A. (2019b). Intestinal infection regulates behavior and learning via neuroendocrine signaling. eLife 8: 50033.

7. Singh, J. and Aballay, A. (2020). Neural control of behavioral and molecular defenses in C. elegans. Curr Opin Neurobiol 62: 34-40.

8. Tran, A., Tang, A., O'Loughlin, C. T., Balistreri, A., Chang, E., Coto Villa, D., Li, J., Varshney, A., Jimenez, V., Pyle, J., Tsujimoto, B., Wellbrook, C., Vargas, C., Duong, A., Ali, N., Matthews, S. Y., Levinson, S., Woldemariam, S., Khuri, S., Bremer, M., Eggers, D. K., L'Etoile, N., Miller Conrad, L. C. and VanHoven, M. K. (2017). $\underline{\text { C. elegans avoids toxin-producing Streptomyces }}$ using a seven transmembrane domain chemosensory receptor. eLife 6: e23770.

9. Wollenberg, A. C., Visvikis, O., Alves, A. F. and Irazoqui, J. E. (2013). Staphylococcus aureus killing assay of Caenorhabditis elegans. Bio-protocol 3(19): e916.

10. Zhang, Y., Lu, H. and Bargmann, C. I. (2005). Pathogenic bacteria induce aversive olfactory learning in Caenorhabditis elegans. Nature 438(7065): 179-184. 